\title{
Pengembangan Media Pembelajaran Biologi Berbasis Adobe Flash untuk Meningkatkan Penguasaan Kompetensi pada Kurikulum 2013
}

\author{
Gista Ratih Astatin ${ }^{1} *$, Heru Nurcahyo ${ }^{2}$ \\ ${ }^{12}$ Program Studi Pendidikan Biologi, Program Pascasarjana, Universitas Negeri Yogyakarta. Jalan \\ Colombo No. 1, Karangmalang, Yogyakarta, 55281, Indonesia \\ * Korespondensi Penulis. Email: gistaratihastatin@gmail.com, Telp: +62274-550836
}

\begin{abstract}
Abstrak
Penelitian ini bertujuan untuk menghasilkan produk media pembelajaran biologi berbasis Adobe flash untuk peserta didik kelas, untuk mengetahui pengaruh media pembelajaran biologi berbasis Adobe flash terhadap penguasaan kompetensi peserta didik. Penelitian pengembangan ini mengacu langkah yang dikembangkan oleh Borg \& Gall. Desain pengembangan dikelompokkan atas tiga prosedur, yang meliputi: (a) studi pendahuluan (b) pengembangan produk awal dan (c) evaluasi/ penilaian produk. Subjek coba terdiri atas ahli materi, ahli media, teman sejawat, guru biologi, peserta didik sejumlah 102 peserta didik. Data diperoleh melalui kuesioner dan soal. Data dianalisis secara kuantitatif dan uji anacova. Hasil penelitian menunjukkan bahwa media pembelajaran ditinjau dari aspek kualitas materi pembelajaran, kualitas design dan strategi pembelajaran dan kualitas teknis tampilan menurut ahli media dan ahli materi berkategori "baik". Menurut teman sejawat, guru biologi dan peserta didik berkategori "sangat baik". Penggunaan media flash berpengaruh lebih baik terhadap penguasaan kompetensi dibandingkan tanpa menggunakan media flash.
\end{abstract}

Kata Kunci: media pembelajaran, sistem saraf, penguasaan kompetensi

\section{Developing Adobe Flash-Based Biology Instruction Media to Improve the Mastery of Competency in Curriculum 2013}

\begin{abstract}
The research aims to develop Adobe flash-based biology instruction media, reveal the effect of teaching media on students' competence mastery. The developmental study refers to the model suggested by Borg \& Gall. The developmental design was grouped into three developmental procedures, consisting of: preface study, developmental first product, and evaluation/ product assesment. Subject consist of subject matter expert, learning media expert, biology teacher, colleagues, 102 students. Data colected by questionnaires and tests. Data were analyzed by quantitatively and anacova. The research findings reveal that the teaching media in term of quality of teaching content aspect, quality of design and teaching strategy aspect, quality of technical and appereance is categorized by subject matter and learning media expert "good". According to colleagues, biology teachers and students the quality of media based on three aspects is "very good". The aplication of flash media give better effect on the competence mastery compared without aplication of flash media.
\end{abstract}

Keywords: instruction media, nervous system, competence mastery

How to Cite: Astatin, G., \& Nurcahyo, H. (2016). Pengembangan media pembelajaran biologi berbasis adobe flash untuk meningkatkan penguasaan kompetensi pada Kurikulum 2013. Jurnal Inovasi Pendidikan IPA, 2(2), 165-176. doi:http://dx.doi.org/10.21831/jipi.v2i2.10966

Permalink/DOI: http://dx.doi.org/10.21831/jipi.v2i2.10966 


\section{PENDAHULUAN}

Pengembangan kurikulum 2013 bertujuan pada pembentukan kompetensi dan karakter peserta didik, berupa paduan pengetahuan, keterampilan dan sikap yang dapat didemonstrasikan peserta didik sebagai wujud pemahaman terhadap konsep yang dipelajari secara kontekstual. Sistem saraf merupakan salah satu materi pada kurikulum 2013. Berdasarkan Peraturan Menteri Pendidikan dan Kebudayaan No 21 tahun 2016 tentang standar isi pendidikan dasar dan menengah, kompetensi yang dicapai pada materi sistem saraf salah satunya yaitu memahami ruang lingkup biologi dan aplikasinya di era konseptual abad XXI dan menerapkan dalam perencanaan karir di masa depan. Berdasarkan komptensi pada kurikulum 2013 ruang lingkup sistem saraf yaitu struktur dan fungsi, klasifikasi, mekanisme proses, kelainan sistem saraf dan pengaruh psikotropika terhadap sistem saraf. Struktur dan fungsi sistem saraf terdiri atas bagian-bagian penyusun sel saraf (dendrit, badan sel, akson, selubung myelin, nukleus, Nodus Renvier, sel Schwan) beserta fungsinya, macam-macam sel saraf (neuron sensoris, neuron motoris dan interneuron) dan fungsi sistem saraf. klasifikasi sistem saraf yang dipelajari yaitu sistem saraf pusat dan sistem saraf tepi, yang di dalamnya memiliki bagian-bagian penyusun dari kedua sistem saraf tersebut. Mekanisme pada sistem saraf mencakup mekanisme gerak refleks, mekanisme proses penghantaran impuls (aksi potensial) pada neuron serta mekanisme penghantaran impuls melalui sinap. Pengaruh psikotropika terhadap sistem saraf mencakup jenis-jenis psikotropika dan efek yang ditimbulkan pada sistem saraf. Kelainan pada sistem saraf mencakup penyakit-penyakit yang menyerang pada sistem saraf. Hasil wawancara guru dan peserta didik menunjukan bahwa guru kesulitan memberi gambaran konkret materi sistem saraf kepada peserta didik, sehingga peserta didik kesulitan mempelajari sistem saraf, hal ini didukung dengan hasil ulangan harian pada materi sistem saraf, sebanyak $69 \%$ peserta didik mendapatkan nilai di bawah KKM (tidak lulus), pembelajaran menggunakan metode teacher center, variasi media pembelajaran yang digunakan masih terbatas. Materi sistem saraf tergolong sulit, menurut peserta didik sub materi yang tersulit adalah struktur fungsi dan mekanisme proses. Pada struktur fungsi memiliki banyak komponen penyusun dan terdapat banyak istilah latin, letak penyusun sel saraf saling berdekatan sehingga peserta didik kesulitan dalam menentukan nama beserta fungsi dari komponen penyusun sel saraf. Pada mekanisme proses peserta didik kesulitan memahami proses aksi potensial, sinap dan gerak refleks karena ketiga proses berlangsung kompleks. Hal ini merupakan faktor penghambat dalam pembelajaran biologi materi sistem saraf. Salah satu dampak materi yang sulit dipahami menyebabkan minat belajar peserta didik rendah, karena peserta didik kurang bersemangat, merasa jenuh dan bosan sehingga materi diserap kurang maksimal sehingga berimbas pada penguasaan kompetensi berupa pemahaman konsep peserta didik rendah. Pembelajaran biologi menekankan interaksi antara peserta didik dan objek yang terdiri atas benda dan kejadian, proses dan produk. Interaksi memberi peluang kepada peserta didik untuk berlatih belajar dan mengerti bagaimana proses/ tahapan belajar, mengembangkan potensi rasional, keterampilan dan kepribadian serta mengenal biologi dan pengkajiannya (Suratsih, 2010, p.8). Sistem saraf tidak dapat memberikan pengalaman langsung, sehingga menggunakan pengganti dengan cara menggunakan media. Menurut Santyasa (2007, p.5) salah satu fungsi media yaitu memperoleh gambaran yang jelas tentang benda/halhal yang sukar diamati secara langsung karena ukurannya yang tidak memungkinkan, baik terlalu besar maupun terlalu kecil. Penggunaan media dapat membantu peserta didik untuk mengkonstruksi konsep dari rumit menjadi sederhana, karena melaui media dapat memvisualisasikan dan memberikan gambaran yang jelas pada konsep sistem saraf sehingga memudahkan untuk memahami sistem saraf. Salah satu jenis media yang digunakan adalah multimedia karena multimedia berisi kombinasi teks, grafik, animasi audio dan video dalam satu teknologi seperti komputer atau televisi (Bates \& Poole, 2003, p.60). Multimedia memiliki keunggulan diantaranya membuat pembelajaran lebih bermakna, meningkatkan pengalaman belajar dan peserta didik menjadi lebih nyaman sehingga membuat peserta didik termotivasi, memiliki minat dan bersemangat (Daesang, Doong-Joong, Woo-Hyung, 2013, p.80). Adobe flash merupakan salah satu jenis aplikasi yang tergolong multimedia karena memiliki kombinasi teks grafik, animasi, audio dan video dalam satu teknologi seperti komputer. Adobe flash dapat mengatasi kesulitan pada pembelajaran sistem saraf karena Adobe flash memiliki kelebihan diantaranya: dapat membuat ilustrasi 
secara detail, animasi yang dibuat memerlukan memori yang kecil, layout yang dibuat sesuai kreatifitas pengembang, dapat dibuat tombol navigasi. Animasi dan gambar konsisten dan fleksible untuk ukuran jendela dan resolusi layar berbagai ukuran pada monitor pengguna, kualitas gambar terjaga, program yang dihasilkan interaktif, menyediakan fitur-fitur yang menarik. Pengembangan media khususnya pembelajaran biologi sudah dilakukan di SMAN 2 Pemalang diantaranya buku elektronik dan modul, namun SMAN 2 Pemalang belum pernah mengembangkan media berbasis Adobe flash dan sekolah sudah memiliki laboratorium komputer yang memadai namun belum digunakan secara optimal untuk pembelajaran biologi. Berdasarkan latar belakang masalah diatas, untuk mengatasi masalah dan memberi solusi terdapat kesulitan diatas, maka peneliti bermaksud mengembangkan media pembelajaran biologi materi sistem saraf berbasis Adobe flash. Adanya media pembelajaran biologi sistem saraf berbasis Adobe flash disusun untuk dapat meningkatkan penguasaan kompetensi berupa pemahaman konsep peserta didik di SMAN 2 Pemalang.

Tujuan pengembangan pada penelitian ini adalah (1) untuk menghasilkan produk media pembelajaran biologi berbasis Adobe flash untuk peserta didik kelas XI IPA di SMAN 2 Pemalang. (2) untuk mengetahui pengaruh media pembelajaran biologi berbasis Adobe flash terhadap penguasaan kompetensi berupa pemahaman konsep peserta didik kelas XI IPA di SMAN 2 Pemalang.

Definisi operasional media pembelajaran yaitu suatu alat bantu yang digunakan untuk menyampaikan informasi dari sumber kepada penerima, sehingga penerima mamahami informsi tersebut. Pada penelitian ini penerima adalah peserta didik. Media yang digunakan pada penelitian ini menggunakan multimedia dan jenis multimedia pada penelitian ini adalah software Adobe flash. Pada kurikulum 2013 di jenjang pendidikan sekolah menengah peminatan IPA, salah satu konsep pada pelajaran biologi adalah sistem saraf. Ruang lingkup materi sistem saraf mencakup pengertian sistem saraf, struktur dan fungsi, klasifikasi/pengelompokan sistem saraf, mekanisme proses penghantaran impuls, jenis psikotropika yang menyerang sistem saraf, kelainan pada sistem saraf. minat belajar merupakan kecenderungan ketertarikan pada sesuatu yang relatif tetap untuk memperhatikan dan mengingat dengan perasaan senang.
Pada penelitian ini minat belajar mencakup perasaan senang, rasa ingin tahu, perhatian dan partisipasi pada pembelajaran. Kompetensi merupakan pengetahuan, keahlian dan kemapuan yang harus dimiliki, dikuasai dan dihayati dengan rasa tanggung jawab oleh seseorang (peserta didik) sehingga peserta didik dapat menjalankan penampilan kogmisi, afeksi dan psikomotorik tertentu. Kompetensi yang dicapai pada materi sistem saraf yaitu memahami ruang lingkup biologi dan aplikasinya di era konseptual abad XXI dan menerapkan dalam perencanaan karir di masa depan, sehingga kompetensi yang dicapai yaitu mencakup pemahaman. Pemahaman konsep adalah proses atau perbuatan untuk mengerti atau tahu benar dan dapat membangun hubungan tentang abstraksi peristiwa, objek berisi sejumlah fakta yang menggambarkan ciri-ciri karakter tertentu yang pernah diketahui sebelumnya dengan fakta yang baru diterimanya.

\section{METODE}

Penelitian ini adalah Research Development (penelitian pengembangan). Metode yang digunakan untuk menghasilkan produk tertentu, dan menguji kevalidan, kepraktisan dan kefektifan produk tersebut. Produk yang dikembangkan adalah media pembelajaran biologi materi sistem saraf berbasis Adobe flash. Penelitian ini menggunakan model bersifat deskriptif yang dikemukakan (Borg \& Gall, 1983 p.775) dengan langkah penelitian sebagai berikut: (1) melakukan studi pendahuluan dan pengumpulan informasi mencakup kajian pustaka, pengamatan kelas dan membuat kerangka kerja penelitian, (2) melakukan perencanaan yang mencakup merumuskan tujuan penelitian memperkirakan dana dan waktu yang diperlukan, prosedur kerja penelitian dan berbagai bentuk partisipasi kegiatan selama kegiatan penelitian, (3) Mengembangkan produk awal, (4) melakukan uji coba awal, melakukan percobaan draf produk ke wilayah subyek terbatas, (5) melakukan revisi untuk menyusun produk utama (revisi produk berdasarkan uji coba awal), (6) melakukan uji coba lapangan utama yaitu uji coba terhadap produk hasil revisi ke wilayah dari subyek yang luas, (7) melakukan revisi untuk meyusun produk operasional, (8) melakukan uji coba lapangan produk operasional, dalam hal ini dilakukan untuk menguji kefektifan produk, (9) melakukan revisi produk final (revisi produk yang efektif dan adaptabel), (10) diseminasi dan implementasi produk hasil pengembangan. 
Penelitian ini dilakukan pada bulan Maret-Mei 2016. Tempat penelitian di SMA N 2 Pemalang. Subjek penelitian dibagi menjadi dua yaitu subjek penilaian terdiri atas riviewer internal dan reviewer eksternal dan subjek uji coba yaitu peserta didik kelas XI IPA. Reviewer internal terdiri atas dosen ahli materi dan ahli media. reviewer eksternal terdiri atas teman sejawat dan guru biologi. Subjek uji coba terdiri atas 5 peserta didik untuk uji coba satu-satu, 15 peserta didik untuk uji coba terbatas, 82 peserta didik untuk uji coba lapangan.

Prosedur pengembangan pada penelitian ini meliputi tiga tahap yaitu: (1) studi pendahuluan, (2) produksi media, (3) penilaian/ evaluasi media. Studi pendahuluan terdapat dua tahap yaitu survei lapangan dan analisis peserta didik. Produksi media memiliki beberapa langkah yaitu membuat flowchart view, membuat storyboard, mengumpulkan bahan seperti materi struktur fungsi, klasifikasi, mekanisme proses, kelainan/penyakit sistem saraf dan psikotropika yang menyerang saraf, mengumpulkan animasi sistm saraf video dan gambar pendukung, memasukan bahan/ materi sistem saraf ke dalam komputer menggunakan aplikasi Adobe flash, melakukan uji modular. Penilaian/evaluasi memiliki tahap memvalidasi produk pada dosen ahli, yaitu dosen ahli materi dan ahli media, melakukan peer reviewer kepada 1 guru biologi dan 3 teman sejawat. Melakukan uji coba oleh peserta didik. Uji coba terdiri atas 3 tahap yaitu uji coba satu-satu dilakukan kepada 5 orang peserta didik, uji coba terbatas dilakukan kepada 15 peserta didik, uji coba lapangan dilakukan kepada 40 peserta didik. Uji coba lapangan menggunakan desain non equivalent control group design (Cohen, Manion \& Marrison, 2007, p. 282). Desain disajikan pada Tabel 1.

Tabel 1. Rancangan Penelitian

\begin{tabular}{llll}
\hline Kelas & Pretest & Perlakuan & Posttest \\
\hline A & O1 & X1 & O2 \\
B & O1 & X2 & O2 \\
\hline
\end{tabular}

Keterangan

A $\quad$ Kelas Perlakuan

$\mathrm{B}=$ Kelas Kontrol

O1 = Pretest kelas perlakuan dan kontrol

$\mathrm{O} 2=$ Posttest kelas perlakuan dan kontrol

$\mathrm{X} 1=$ Menggunakan media flash

X2 = Menggunakan media buku

Jenis instrumen yang digunakan yaitu angket penilaian produk. Angket digunakan untuk memvalidasi dan mengevaluasi kualitas produk yang dikembangkan, baik dari aspek kualitas materi pembelajaran, aspek kualitas desain dan strategi, aspek kualitas teknis dan tampilan. Lembar angket penilaian produk menggunakan skala likert dengan 5 alternatif pilihan. Reviewer membubuhkan tanda centang pada kolom yang telah disediakan. Data yang dihasilkan berupa data kualitatif yang diubah menjadi data kuantitatif.

\section{Angket Minat Belajar}

Angket ini digunakan untuk menilai minat belajar peserta didik menggunakan media belajar berbasis Adobe flash pada saat pembelajaran. Lembar angket minat belajar menggunakan skala likert dengan 5 alternatif pilihan. Peserta didik membubuhkan tanda centang pada kolom yang telah disediakan. Data yang dihasilkan berupa data kualitatif yang diubah menjadi data kuantitatif.

Soal tes digunakan untuk mengetahui tingkat pemahaman peserta didik terhadap materi ajar (sistem saraf) setelah peserta didik belajar dengan media pembelajaran. Tes ini terdiri pretest dan posttest. Tipe soal adalah asosiasi pilihan ganda dan isian singkat. Ranah kognitif yang diukur mengikuti taksonomi bloom yaitu ingatan $(\mathrm{C} 1)$ dan pemahaman $(\mathrm{C} 2)$.

Validasi Instrumen minat belajar dilakukan dengan cara mengkonsultasikan instrumen kepada ahli materi. Revisi instrumen dilakukan berdasarkan masukan dari ahli materi.Validasi intrumen tes dilakukan dengan dua cara yaitu validasi teoritis yang terdiri validasi isi dan validasi konstruk dengan cara mengkonsultasikan instrumen kepada ahli materi. Validasi empiris dilakukan setelah validasi teoritik dengan cara mengujicobakan instrumen tes dengan jumlah 40 soal kepada 40 peserta didik kelas XII IPA 1, kemuadian dilakukan analisis menggunakan Quest. Setelah dilakukan analisis terdapat 37 item masuk dalam batas INFIT MNSQ sehingga dapat dinyatakan bahwa 37 item fit dengan model. Peneliti mengambil 20 item yang akan digunakan pada uji coba lapangan. Reliabilitas instrumen dilakukan menggunakan program Quest. Hasil menunjukkan bahwa item fit dengan model artinya item realiabel. Koefisien kappa sebesar 0,09.

Analisis yang dilakukan pada data kualitatif berupa saran dan komentar yang diberikan reviewer 1 dan reviewer II terhadap produk yang dihasilkan. Saran yang relevan selanjutnya digunakan sebagai dasar untuk revisi produk. Analisis data kuantitatif memiliki langkah-langkah untuk menentukan kriteria kualitas produk sebagai berikut: (1) pengubahan nilai kualitatif 
menjadi kuantitatif. (2) rekapitulasi penilaian dan penghitungan skor rata-rata untuk setiap aspek kriteria yang dinilai, rumus yang digunakan yaitu:

$$
\mathbf{X}=\frac{\sum x}{n}
$$

(3) menginterpretasi secara kualitatif jumlah rata-rata skor tiap aspek dengan menggunakan rumus konversi 5, dengan skor perhitungan skor 1 dan skor maksimal 5 sehingga diperoleh rerata ideal $(\mathrm{Xi})=3$ dan $\mathrm{Sbi}=0,67$. Analisis minat belajar dilakukan dengan cara pengubahan nilai kualitatif menjadi kuantitatif dengan skor minimal 1 dan skor maksimal 5. Peningkatan minat dihitung menggunakan teknik normalisasi gain. Rumus yang digunakan yaitu:

$\mathrm{g}=\frac{(\text { skor postest }- \text { skor pretest })}{(\text { skor maksimal-skor pretest })}$

Keterangan:

$\mathrm{g}=$ nilai normalized gain

skor posttest $\quad=$ skor posttest

skor pretest $=$ skor pretest

Kriteria gain menurut Hake (1998, p.65) disajikan pada Tabel 2.

Tabel 2. Kriteria Indeks Gain

\begin{tabular}{cc}
\hline Indeks Gain & Kriteria \\
\hline $\mathrm{g}>0,70$ & Tinggi \\
$0,30<\mathrm{g}<0,70$ & Sedang \\
$\mathrm{g} \leq 0,30$ & Rendah \\
\hline
\end{tabular}

Data tes pemahaman dilakukan analisis menggunakan uji statistik deskriptif kuantitatif yaitu uji prasyarat menggunakan uji normalitas dan uji homogenitas. Uji hipotesis menggunakan uji analisis kovarian (Anacova). Mengitung Indeks Senstivitas Soal

Rumus:

$$
\mathrm{S}=\frac{\boldsymbol{R} \boldsymbol{a}-\boldsymbol{R} \boldsymbol{b}}{\boldsymbol{T}}
$$

$\mathrm{S}=$ Sensitivitas pengaruh pengajaran

$\mathrm{Ra}=\sum$ siswa menjawab benar sesudah proses pengajaran

$\mathrm{Rb}=\sum$ siswa menjawab benar sebelum proses pengajaran

$\mathrm{T}=$ total siswa mengikuti kedua proses testing

\section{HASIL DAN PEMBAHASAN}

Hasil wawancara guru biologi dan siswa kelas XII yaitu materi sistem saraf merupakan materi yang sulit dipelajari karena terdapat istilah latin, tergolong cukup abstrak dan rumit sehingga perlu adanya media untuk membantu peserta didik untuk memahami materi sistem saraf dan dikemas dengan menarik agar peserta didik tertarik mempelajari sistem saraf. Salah satu aplikasi dapat membuat media yang menarik adalah Adobe flash.

Analsis materi pembelajaran dilakukan dengan cara mengidentifikasi KI dan KD materi sistem saraf. KD yang telah ditetapkan kemudian dijabarkan kedalam bentuk indikator pembelajaran. Materi yang dibuat pada media Adobe flash yaitu: Struktur dan fungsi, Klasifikasi, Mekanisme proses, Kelainan sistem saraf, pengaruh psikotropika terhadap sistem saraf. Layout media pembelajaran yang dirancang yaitu menu pertama berisi video berhubungan sistem saraf, menu kedua berisi KI, KD dan Indikator, menu ketiga berisi materi sistem saraf, menu keempat berisi latihan soal berisi 20 pertanyaan, menu kelima berisi profil pengembang.

Hasil produk yang dikembangkan materi sistem saraf adalah bagian pertama video sistem saraf, bagian kedua menampilkan 4 menu yaitu KI dan KD, Materi, Kuis dan Profil. Bagian materi terdapat 5 sub materi yaitu struktur fungsi, klasifikasi, mekanisme proses, pengaruh psikotropika terhadap sistem saraf, kelainan pada sistem saraf. Bagian kuis menampilkan 20 pertanyaan pilihan ganda beserta jawaban. Bagian profil menampilkan profil peneliti.

Penilaian produk media pembelajaran oleh teman sejawat, ahli materi, ahli media, guru biologi dan peserta didik ditunjukkan pada Gambar 1.

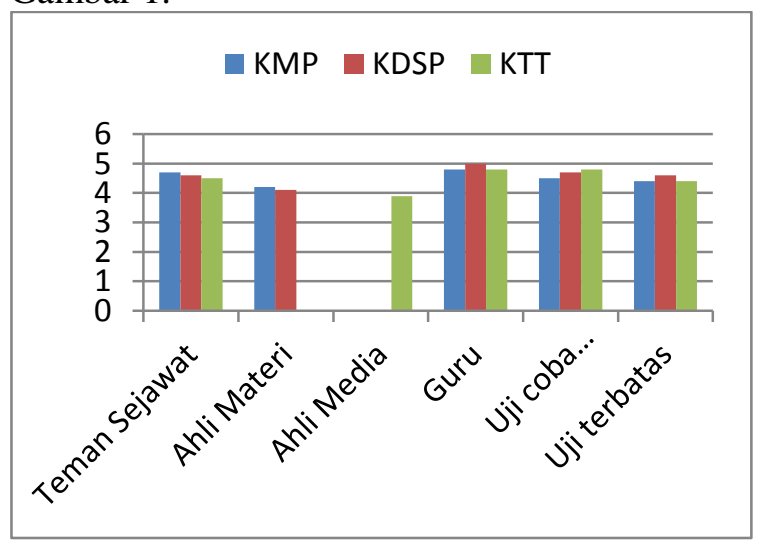

Keterangan: KMP= Kualitas Materi Pembelajaran, $\mathrm{KDSP}=$ Kualitas Design dan Strategi Pembelajaran, KTT $=$ Kualitas Teknis dan Tampilan.

Gambar 1. Hasil Penilaian Produk oleh Teman sejawat, Ahli Materi, Ahli Media, Guru Biologi,

Uji Coba satu-satu dan Uji Coba Terbatas.

Berdasarkan Gambar 1. pada penilaian yang diberikan oleh ahli materi dan ahli media dikategorikan "baik" karena skor lebih besar 3,40 dan lebih kecil dari 4,21 $(3,40<\mathrm{X} \leq 4,21)$ 
sehingga produk layak untuk diujicoba pada tahap selanjutnya. Hasil penilaian produk menunjukkan pada penilaian yang diberikan oleh teman sejawat, guru biologi, peserta didik dikategorikan "sangat baik" karena ketiga skor lebih besar dari 4,21 (X>4,21) sehingga media layak untuk uji coba lapangan.

Saran yang diberikan oleh ahli materi yaitu materi klasifikasi atau pengelompokkan pada saraf tepi dipisah dan saran yang diberikan oleh ahli media yaitu keluasan materi yang terkandung dalam materi perlu ditingkatkan, interaktivitas media dan pembelajaran perlu difasilitasi lebih baik, fungsi media yang dapat meningkatkan minat dan pemahaman konsep perlu diperluas dan diperbanyak. Saran yang diberikan oleh teman sejawat yaitu sound yang digunakan sebaiknya lebih lambat, perlu diberikan petunjuk penggunaan media. komentar yang diberikan guru biologi adalah Adobe flash yang dikembangkan sangat baik, mampu menarik perhatian dan minat peserta didik dalam mempelajari sistem saraf, sehingga mampu meningkatkan pemahaman konsep. Saran yang diberikan oleh guru biologi yaitu sebaiknya ditambah pengertian sistem saraf, diberi gambar arah jalannya impuls secara umum dan letak keterangan fungsi bagian sel saraf tidak menutupi gambar dari struktur sel saraf. Saran yang diberikan oleh peserta didik yaitu masih terdapat kata-kata dan pengetikan yang salah sehingga perlu diperbaiki.

Revisi tahap pertama dilakukan setelah produk divalidasi oleh teman sejawat, ahli media, ahli materi. Revisi tahap pertama antara lain: penambahan petunjuk pengoperasian media pembelajaran, pada slide materi diberi nomor urut yaitu (1) struktur fungsi, (2) Klasifikasi, (3) mekanisme proses, (4) pengaruh psikotropika terhadap sistem saraf, (5) Kelainan sistem saraf. Hal ini bertujuan agar peserta didik dapat membuka materi secara runtut, materi sistem saraf diperluas karena terlalu dangkal. Adapun revisi penambahan yaitu pengaruh psikotropika terhadap sistem saraf dan kelainan pada sistem saraf, latihan soal diperbanyak dan langsung ditampilkan jawaban setelah peserta didik menjawab. Sebelum revisi terdapat 10 butir latihan soal setelah direvisi terdapat 20 butir latihan soal, gambar dibuat terlihat semua dalam satu layar, agar peserta didik dapat mengetahui secara keseluruhan. Sebelum revisi gambar perlu ditekan tombol scroll down, setelah revisi gambar terlihat utuh tanpa ditekan tombol scroll down, gambar disertakan dengan sumber. Sebe- lum revisi gambar tidak disertakan dengan sumber, setelah revisi gambar disertakan dengan sumber, huruf yang digunakan harus konsistem baik ukuran dan jenis huruf. Sebelum revisi terdapat lebih dari satu jenis huruf dan ukuran. Setelah revisi media memilki satu jenis huruf dan ukuran, audio terlalu cepat sehingga diganti yang lebih lambat, pada bahsan sistem saraf tepi dipisah dari slide peta konsep

Revisi tahap kedua dilakukan setelah melakukan penilaian oleh guru biologi. Revisi tahap kedua antara lain: video diberi judul. Sebelum revisi hanya berupa video. Setelah revisi terdapat judul dan pengantar pada video yang letaknya dibawah video, menambahkan pengertian sistem saraf. sebelum revisi hanya terdapat pengantar materi sistem saraf. setelah revisi terdapat penambahan pengertian sistem saraf setelah paragraf pengantar sistem saraf, penambahan alur jalannya impuls saraf, keterangan pada struktur saraf digeser agar tidak menutupi gambar sel saraf. Sebelum revisi keterangan nomor 3 dan 5 menutupi gambar struktur sel saraf. Setelah revisi keterangan nomor 3 dan 5 tidak menutupi gambar sel saraf.

Revisi tahap ketiga dilakukan setelah uji terbatas. Revisi tahap ketiga mencakup penulisan kata-kata perlu diperbaiki dan masih terdapat pengetikan yang belum benar. Audio tidak terdengar pada uji coba satu-satu dan terbatas karena computer yang digunakan tidak dilengkapi dengan speaker.

Pada aspek materi, penilaian yang diberikan ahli materi adalah baik, penilaian yang diberikan teman sejawat, guru biologi dan peserta didik adaah sangat baik hal ini dikarenakan literatur yang digunakan dalam pembuatan media dapat dipertanggungjawabkan. Pada aspek kualitas teknis dan tampilan, penilaian yang diberikan oleh ahli media adalah baik, penilaian yang diberikan teman sejawat, guru biologi dan peserta didik adalah sangat baik, hal ini karena media memiliki tampilan yang dapat menarik minat peserta didik, serta memberi kemudahan sehingga peserta didik dapat memahami materi sistem saraf. Pada aspek desain dan strategi pembelajaran, penilaian yang diberikan oleh ahli materi yaitu baik, penilaian yang diberikan oleh guru, teman sejawat dan peserta didik adalah sangat baik. Hasil penilaian memperlihatkan bahwa desain dan strategi pembelajaran memudahkan peserta didik untuk memahami materi sistem saraf.

Pada uji coba lapangan dilakukan dalam bentuk pembelajaran dikelas XI IPA di SMAN 2 
Pemalang. Pada uji coba lapangan mengukur penguasaan kompetensi berupa pemahaman konsep dengan menggunakan media pembelajaran yang telah direvisi. Penelitian ini bertujuan untuk meningkatkan pemahaman konsep peserta didik, untuk mengatahui media dapat meningkatkan pemahaman konsep maka diakan pretest dan posttest. Pretest dan posttest materi sistem saraf dilaksanakan di kelas XI IPA 1 sebagai kelas perlakuan dengan 40 peserta didik dan kelas XI IPA 2 sebagai kelas kontrol dengan 42 peserta didik. Pembelajaran kelas kontrol menggunakan buku, kelas perlakuan menggunakan media Adobe flash. Hasil nilai rata-rata nilai pada kelas kontrol dan kelas perlakuan ditunjukan pada Gambar 2.

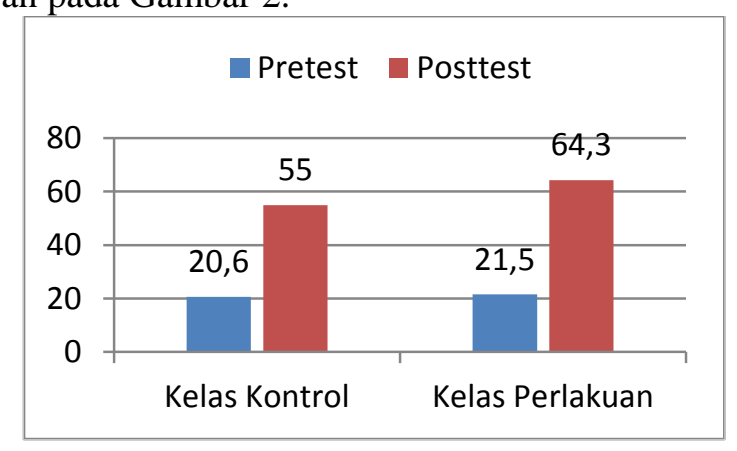

Gambar 2. Nilai rata-rata pemahaman konsep

Uji normalitas dilakukan bertujuan untuk mengetahui sebaran data yang dianalisis. Hasil uji normalitas menunjukkan hasil pretest dan posttest baik kelas kontrol maupun kelas perlakuan terdistribusi normal karena niai sig. > 0,05. Nilai .sig pada pretest kelas perlakuan 0,66, kelas kontrol 0,90. Nilai .sig pada posttest kelas perlakuan 0,72. Kelas kontrol 0,228. Uji homogenitas dilakukan bertujuan untuk mengetahui apakah sampel berasal dari populasi yang homogen atau tidak. Hasil uji homogenitas menunjukkan hasil pretest dan posttest baik kelas kontrol maupun kelas perlakuan bersifat homogen karena nilai sig. $>0,05$. Nilai sig. pada pretest yaitu 0,736 dan posttest 0,112 .

Uji anacova dilakukan bertujuan untuk melihat pengaruh perlakuan terhadap posttest dengan mengontrol pretest. Hasil uji anacova menunjukan hasil posttest dipengaruhi oleh media karena nilai signifikansi $<0,05$. Rata-rata nilai posttest kelas perlakuan lebih tinggi dibandingkan posttest kelas kontrol, hal ini dikarenakan multimedia dapat membantu peserta didik lebih mudah memahami materi yang telah dipelajari. Gilakjani (2012, p.58) menyatakan beberapa studi menunjukkan bahwa multimedia berbasis komputer dapat meningkatkan pembel- ajaran dan ingatan materi yang disampaikan selama dikelas dibandingkan dengan pembelajaran yang tidak menggunakan multimedia. Peningkatan ini dikaitkan dengan adanya coding ganda dari informasi yang disajikan. Informasi pada multimedia memiliki dua modalitas yaitu visual ditambah pendengaran. Coding diproses teori CTML (Cognitive Theory Multimedia Learning) yang dikemukan oleh Mayer. Menurut (Shorden, 2012, p.3) didalam teori CTML bahwa ada lima bentuk yang diproses oleh memori. Bentuk pertama adalah kata-kata yang diucapkan dan gambar pada saat mempresentasikan materi pada multimedia itu sendiri. Bentuk kedua suara ditangkap oleh telinga dan gambar ditangkap oleh mata didalam memori sensorik. Bentuk ketiga adalah suara dan gambar dalam memori kerja. Bentuk keempat adalah model verbal dan model piktoral juga terdapat didalam memori kerja dan bentuk kelima adalah pengetahuan sebelumnya yang disimpan dimemori jangka panjang diintegrasikan verbal dan pictoral. Menurut Sudjana \& Rivai (1991, p.43) media dapat membuat bahan pengajaran akan jelas maknanya sehingga lebih mudah dipahami oleh peserta didik dan memungkinkan peserta didik menguasai tujuan pembelajaran yang lebih baik. Media pembelajaran meminimalisir verbalisme yaitu proses pembelajaran peserta didik hanya diberi pengalaman (pengetahuan, sikap dan keterampilan) melalui kata-kata saja, serta peserta didik lebih banyak melakukan kegiatan belajar, sebab tidak hanya mendengarkan guru, tetapi juga aktifitas lain seperti mengamati, melakukan, mendemonstrasikan, sehingga peserta didik mendapatkan pengalaman bermakna dan pemahaman konsep meningkat. Media membuat peserta didik terlibat aktif dalam pembelajaran. Menurut Joshi (2012, p.34) melalui interaksi dengan multimedia pada materi yang menarik, peserta didik menjadi akrab dengan materi yang dipelajari dan peserta didik menjadi aktif terlibat dalam proses pembelajaran. Menurut Shah \& Khan (2015, p.356), multimedia merupakan alat belajar dan mengajar yang inovatif dan efektif karena dapat membantu peserta didik untuk memotivasi mereka pada saat proses pembelajaran dan membantu memahami informasi atau materi yang disampaikan. Multimedia juga membantu guru dalam penyampaian informasi. Peserta didik menjadi aktif terlibat dalam proses belajar mengajar. Multimedia lebih efektif untuk mengembangkan aspek kognisi dan sikap peserta didik dan membantu untuk mengembangkan keterampilan kognisi tingkat 
tinggi dan sikap peserta didik terhadap pembelajaran, dengan menggunakan animasi, suara, video dan klip audio membuat pembelajaran menjadi menarik.

Hasil penelitian ini sesuai dengan hasil penelitian Kingsley \& Boone (2008, p. 203) bahwa terdapat peningkatan hasil belajar yang signifikan menggunakan program software sejarah Amerika berbasis multimedia. Hasil penelitian SERIN (2011, p.183) juga menunjukkan ada peningkatan signifikan pada prestasi dan pemecahan masalah pada kelompok perlakuan yang menggunakan komputer berbasis ilmu pengetahuan dan teknologi. Hasil penelitian Mayer, Fennel, Farmer, \& Campbell (2004, p. 389), menyimpulkan bahwa kelas dengan penyampaian materi menggunakan kombinasi teks dan suara, hasil belajar lebih baik dibandingkan kelas menggunakan teks. Hasil penelitian Wahyuni \& Djukri (2016, p. 90) menyimpulkan bahwa pembelajaran menggunakan media berbantuan komputer materi bryophyte efektif meningkatkan penguasaan konsep. Hal ini ditunjukan adanya perbedaan hasil penguasaan konsep yang diperoleh antara kelas kontrol dan kelas treatment.

Hasil tes pemahaman konsep pada kelas perlakuan mengalami peningkatan juga dikarenakan minat belajar mengalami peningkatan. Peningkatan minat pada kelas perlakuan ditunjukkan pada Gambar 3.

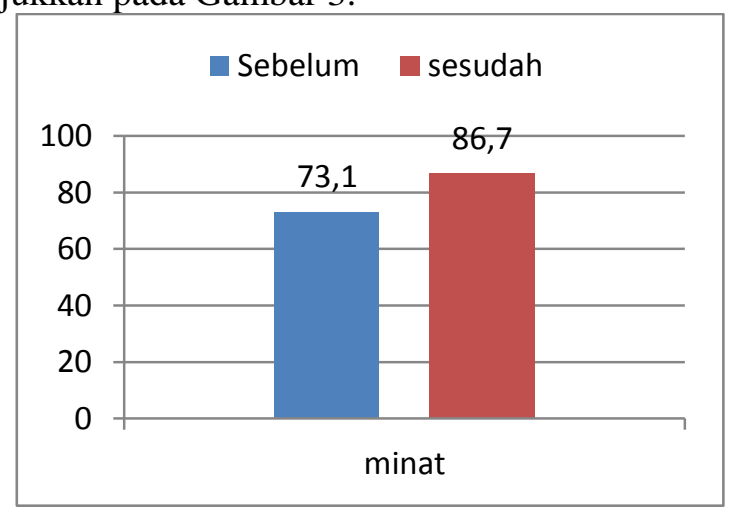

Gambar 3. Hasil rata-rata minat kelas perlakuan

Berdasarkan Gambar 3. dan dilakukan analisis menggunakan gain score, peningkatan minat dikategorikan sedang. Minat yang meningkat dapat berimbas pada pemahaman konsep yang meningkat. Peningkatan minat dikarenakan multimedia memiliki fungsi untuk merangsang perhatian. Perhatian meningkat maka peserta didik menjadi lebih fokus dalam mempelajari sistem saraf sehingga peserta didik menjadi paham dengan konsep sistem saraf. Hal-hal yang dapat merangsang perhatian dan minat peserta didik karena multimedia memiliki 5 element yang saling terintegrasi. Menurut Sharma (2015, p.276), Keuntungan menggunakan multimedia dalam pengajaran yaitu materi menjadi interaktif dan adanya kombinasi gambar dan suara sehingga menjadi lebih jelas. Multimedia memberikan bentuk pengajaran yang bervariasi seperti mendengarkan audio, menonton video, memperhatikan gambar didalam media, sehingga peserta didik tidak cepat bosan dalam mempelajari materi yang diajarkan. Menurut Wang (2010, p.49), media dapat menarik minat peserta didik karena desain multimedia, audio dan efek flash yang dibuat menarik. Menurut Phing \& Kian (2007, p.30) salah satu cara meningkatkan perhatian peserta didik yaitu didalam multimedia terdapat gambar, informasi teks, suara dan latar belakang dengan warna yang kontras. Menurut Ogochukwu (2010, p.107) melalui survei terbaru menunjukkan kelas yang memanfaatkan presentasi menggunakan multimedia, kelas menjadi menarik dan menyenangkan, serta peserta didik berpartisipasi dalam pembelajaran. Di dalam multimedia terdapat berbagai saluran yaitu video, fungsi video adalah untuk memusatkan perhatian peserta didik, selain itu animasi di dalam multimedia berperan untuk memegang perhatian peserta didik. Narasi di dalam animasi efektif dalam mempertahankan perhatian peserta didik, terlebih lagi apabila narasi disajikan dalam bentuk ucapan dan suara di dalam multimedia dapat membuat kata yang dihafalkan akan menjadi lebih ingat. Sistem multimedia akan sukses apabila saluran memiliki porsi yang seimbang. Studi yang dilakukan (Ogochukwu, 2010, p.108) meneliti dampak dari presentasi multimedia menunjukkan guru dalam mempresentasi menggunakan multimedia memiliki sikap yang lebih positif dan peserta didik pada kelompok multimedia lebih menikmati presentasi, konsep lebih dimengerti dan setuju dengan cara penyampaian konsep lebih baik dari pada kelompk tradisional.

Hasil penelitian ini sesuai dengan penelitian Yunus, Salehi, John (2013, p.108) menyimpulkan bahwa pembelajaran dengan bantuan visual (animasi, video, gambar) peserta didik menjadi berkonsentrasi pada saat pembelajaran bahasa inggris. Hasil penelitian Leow (2014, p.99) menyimpulkan dengan menggunakan modul pembelajaran interaktif, mahasiswa bersikap positif, mereka lebih aktif dan termotivasi pada saat proses pembelajaran. Hasil penelitian Patel (2013, p.117), multimedia dapat menumbuhkan minat peserta didik pada saat belajar, 
karena multimedia membuat kita lebih mengakses informasi yang terdapat didalamnya. Hasil penelitian Sari \& Sugiarto (2015, p. 165) menyimpulkan penggunaan multimedia berbasis masalah dalam pembelajaran kimia dapat meningkatkan motivasi belajar dan kemampuan berpikir kritis peserta didik. Hal ini ditunjukan skor motivasi belajar dan kemampuan berpikir kritis peserta didik kelas eksperimen lebih tinggi dibandingkan kelas kontrol. Hasil item tes pemahaman konsep dilakukan analisis menggunakan indeks sensitivitas yang menghasilkan bahwa item tes dikategorikan efektif karena mempunyai nilai $0,00-1,00$. Tabel indeks sensitivitas item soal kelas perlakuan dan kelas kontrol disajikan pada Tabel 3.

Tabel 3. Nilai Indeks Sensitivitas Pemahaman Konsep

\begin{tabular}{|c|c|c|c|}
\hline \multirow{2}{*}{ Bentuk item } & \multirow{2}{*}{$\begin{array}{l}\text { Nomor } \\
\text { Item }\end{array}$} & \multicolumn{2}{|c|}{$\begin{array}{c}\text { Nilai Indeks } \\
\text { sensitivitas }\end{array}$} \\
\hline & & $\begin{array}{c}\text { Kelas } \\
\text { Perlakuan }\end{array}$ & $\begin{array}{c}\text { Kelas } \\
\text { kontrol }\end{array}$ \\
\hline \multirow{11}{*}{$\begin{array}{l}\text { Asosiasi pilihan } \\
\text { ganda }\end{array}$} & Item 1 & 0,15 & 0,10 \\
\hline & Item 2 & 0,28 & 0,21 \\
\hline & Item 3 & 0,68 & 0,48 \\
\hline & Item 4 & 0,53 & 0,36 \\
\hline & Item 5 & 0,40 & 0,40 \\
\hline & Item 6 & 0,55 & 0,45 \\
\hline & Item 7 & 0,40 & 0,24 \\
\hline & Item 8 & 0,30 & 0,26 \\
\hline & Item 9 & 0,35 & 033 \\
\hline & Item & 0,15 & 0,14 \\
\hline & 10 & & \\
\hline \multirow[t]{10}{*}{ Isian singkat } & Item 1 & 0,33 & 0,17 \\
\hline & Item 2 & 0,58 & 0,38 \\
\hline & Item 3 & 0,80 & 0,74 \\
\hline & Item 4 & 0,25 & 0,33 \\
\hline & Item 5 & 0,70 & 0,52 \\
\hline & Item 6 & 0,33 & 0,19 \\
\hline & Item 7 & 0,13 & 0,14 \\
\hline & Item 8 & 0,40 & 0,40 \\
\hline & Item 9 & 0,65 & 0,67 \\
\hline & $\begin{array}{l}\text { Item } \\
10\end{array}$ & 0,63 & 0,36 \\
\hline
\end{tabular}

Proses pembelajaran pada uji terbatas dan uji lapangan, ditemukan hasil diantaranya: Peserta didik tertarik menggunakan media. Hasil pengamatan uji lapangan memperlihatkan bahwa peserta didik tertarik menggunakan media pembelajaran hal ini dilihat pada saat memperoleh media, peserta didik aktif mengoperasikan media tersebut. Peserta didik terlihat senang saat melihat pendahuluan media pembelajaran yaitu berupa video.Peserta didik senang menggunakan media pembelajaran, hasil dari tanggapan peserta didik menjelaskan bahwa peserta didik senang dengan media dan pembelajaran menggunakan media berbasis Adobe flash karena media menyediakan gambar dan keterangan yang mudah dipahami peserta didik dan dikemas dengan pembelajaran yang menyenangkan. Peserta didik aktif pada saat pembelajaran, hasil pengamatan pada uji lapangan menemukan bahawa peserta didik aktif mengoperasikan media. Beberapa peserta didik yang belum jelas bertanya kepada guru pada saat guru mendatangi kelompok. Sikap kerja sama peserta didik muncul pada saat pembelajaran, hasil pengamatan pada uji lapangan menemukan bahwa adanya kerja sama saat diskusi kelompok berlangsung, dalam satu kelompok terlihat saling membantu mengisi LKPD yang telah disediakan sesuai dengan materi yang terdapat di dalam media pembelajaran. Adanya pembagian kerja saat presentasi di depan kelas.

Berdasarkan kajian akhir tersebut dapat dikatakan bahwa media pembelajaran berbasis Adobe flash materi sistem saraf yang dikembangkan merupakan produk yang layak digunakan dalam pembelajaran biologi di lapangan. Kelayakan tersebut didukung oleh rerata penilaian dari ketiga aspek materi, pembelajaran dan tampilan media. Karakteristik lain dari media pembelajaran berbasis Adobe flash yang dikembangkan memiliki keunggulan diantaranya: media pembelajaran yang dikembangkan memiliki kualitas tampilan menarik dan tidak membingungkan, media pembelajaran berbasis Adobe flash mudah dioperasikan, belajar menggunakan media pembelajaran berbasis Adobe flash membuat belajar menjadi menyenangkan karena dilengkapi video, gambar, animasi, dan teks, terdapat latihan soal interaktif yang dapat menarik minat peserta didik untuk menjawab soal tersebut. Media pembelajaran berbasis Adobe flash juga memiliki kelemahan. Beberapa kelemahan pada media pembelajaran ini adalah: media pembelajaran hanya dapat digunakan pada laptop atau Personal Computer (PC) yang sudah terinstall aplikasi Adobe flash, media pembelajaran hanya pada materi sistem saraf.

Keterbatasan penelitian dan pengembangan media pembelajaran berbasis Adobe flash materi sistem saraf adalah: Sampel yang digunakan masih terbatas, hasil pemahaman konsep menggunakan media pembelajaran belum optimal karena SMA N 2 Pemalang baru menggunakan media pembelajaran berbasis Adobe flash, sampel penelitian masih dalam lingkup satu kelas, reliabilitas soal pada segi person masih dalam kategori rendah, dalam studi 
pendahuluan kurang empirik karena masih sebatas wawancara kepada satu guru biologi dan peserta didik kelas XII IPA.

\section{SIMPULAN DAN SARAN}

\section{Simpulan}

Pertama, produk pengembangan merupakan media pembelajaran berbasis Adobe flash, materi yang dipilih adalah sistem saraf. prosedur pengembangan dikelompokan 3 tahap yaitu studi pendahuluan, pengembangan produk awal dan evaluasi. Kualitas produk media pembelajaran berbasis Adobe flash melalui penilaian ahli materi dan ahli media tergolong kriteria baik dan penilaian oleh teman sejawat, guru biologi dan peserta didik tergolong kriteria sangat baik. Kedua, media pembelajaran efektif dalam proses pembelajaran dilihat dari penguasaan kompetensi peserta didik berupa pemahaman konsep terjadi peningkatan pada sebelum dan sesudah menggunakan media pembelajaran berbasis Adobe flash

\section{Saran}

Pertama, penelitian yang dilakukan masih terbatas pada satu sekolah, sehingga media perlu diuji coba lebih dari satu sekolah agar layak digunakan dalam skala besar. Kedua, media yang dibuat sebaiknya lebih banyak menggunakan gambar bergerak dalm bentuk animasi agar peserta didik lebih tertarik dalam mempelajari materi sistem saraf. Ketiga, penginstallan media pembelajaran berbasis Adobe flash sebaiknya sebelum pembelajaran dimulai atau sehari sebelum pembelajaran agar lebih mudah mengefektifkan waktu dalam pembelajaran. Keempat, pembuatan media pembelajaran diperuntukan selain materi sistem saraf khususnya pada materi yang membutuhkan bantuan untuk divisualisasikan.

\section{Diseminasi dan Pengembangan Produk Lebih Lanjut}

Diseminasi produk penelitian meliputi: menyerahkan software media pada guru biologi SMA N 2 Pemalang, agar menjadi bahan untuk pembelajaran materi sistem saraf. Pengembangan produk lebih lanjut meliputi: Media pembelajaran berbasis Adobe flash dapat dikembangkan bentuk latihan soal menjadi game educatif, media berbasis Adobe flash dapat dikembangkan dengan animasi yang lebih banyak, media pembelajaran berbasis Adobe flash dapat dikembangkan lebih lanjut dengan materi yang berbeda tidak hanya pada materi biologi tetapi juga pada materi sains lainnya.

\section{DAFTAR PUSTAKA}

Bates, A.W., \& Poole, G. (2003). Effective teaching with technology in higher education: Fundation for succes. San Franscisco: John Wiley \& Sons, Inc.

Borg, W.R., \& Gall, M.D. (1983). Educational research: An introduction $\left(4^{\text {th }} e d\right)$. New York: Logman Inc.

Cohen, L., Manion, L., Morrison, K. (2007). Research methods in education ( $6^{\text {th }}$ ed). New York: Routledge.

Daesang, K., Doong-Joong, K., \& Woo-Hyung, W. (2013). Cognitive sinergy in multimedia learning. Canadian Center of Science and Education, 6, 76-84.

Gilakjani, A.P. (2012). The significant role of multimedia in motivating EFL learners' interest in english language learning. I.J. Modern Education and Computer Science, 4, 57-66.

Hake, R. R. (1998). Interactive engagement versus traditional metods: A six-thousandstudent survey of mechanics test data for introductaory physics courses. American Journal of Physics, 66 (1), 65.

Santyasa, I. W. (Januari 2007). Landasan konseptual media pembelajaran. Makalah disajikan dalam Work Shop Pembelajaran bagi Guru-Guru SMAN Banjar Angkan, di Banjar Angkan Klungkung.

Joshi, A. (2012). Multimedia: Technique in teaching process in the classrooms. Current World Environment, 7(1), 33-36.

Kingsley, K.V., \& Boone, R. (2008). Effects of multimedia software on achievment of middle school students in an american history class. ProQuest Professional Education, 41, 203-221.

Leow, F.T. (2014). Interactive multimedia learning innovating classroom education in a Malaysian University. The Turkish Journal of Education Technology, 13(2), 99-110.

Mayer, R.E., Fennel, S., Farmer, L., \& Campbell, J. (2004). A personalization effect in multimedia learning: Students learn better when words are in conversational style rather than formal style. American Pschologycal Association, 96, 389-395. 
Ogochukwu, N.V. (2010). Enhancing students interest in mathematics via multimedia presentation. African Journal of Mathematics and Science Research, 3(7), 107-113.

Patel, C. (2013). Use of multimedia technology in teaching and learning communication skill: An analysis. International Journal of Advancements in Research \& Technology, 2(7), 116-123.

Phing, B.S., \& Kian, T. (2007). Interactive multimedia learning: students' attitudes and learning impact in an animation course. The Turkish Journal of Education Technology, 6, 28-37.

Presiden. (2016). Peraturan Menteri Pendidikan dan Kebubadayaan Nomor 21, Tahun 2016, tentang Standar Isi Pendidikan dasar dan Menengah.

Sari, D., \& Sugiyarto, K. (2015). Pengembangan multimedia berbasis masalah untuk meningkatkan motivasi belajar dan kemampuan berpikir kritis siswa. Jurnal Inovasi Pendidikan IPA, 1(2), 153 - 166.

SERIN, O. (2011). The effect of the computerbased instructions on the achievement and problem solving sill of the science and technology students. The Turkish Online Journal of Education Technology, 10, 183-201.
Shah, M., \& Khan, M. (2015). Impact of multimedia-aided teaching on students, academic achievement and attitude at elementary level. David publishing, 5(5), 349-360.

Sharma, H.L. (2015). Enhancing student interest in english language via multimedia presentation. International Journal of Applied Reasearch, 2, 275-281.

Shorden, S.D. (2012). The cognitive theory of multimdia learning. Mohave Community Collage, 1-31.

Sudjana, N., \& Rivai, A. (1991), Media pengajaran. Bandung: Sinar Baru.

Suratsih. (2011). Pengembangan kurikulum biologi. Yogyakarta: UNY Press.

Wahyuni, S., \& Djukri, D. (2016). Pengembangan media pembelajaran berbantuan komputer dan keefektifannya terhadap kemandirian belajar dan penguasaan konsep bryophyte. Jurnal Inovasi Teknologi Pendidikan, 3(1), 7991.

Wang, T.J. (2010). Educational benefits of multimedia skills training. TechTrends, 54, 47-57.

Yunus, M.MD., Salehi, H., \& John, D.S.A. (2013). Using visual aid an a motivational tool in enhancing students' interest in reading literary texts. Recent Advances in Educational Technologies, 114-117. 